\title{
How many rifting events preceded the development of the
}

\section{Araçuaí-West Congo orogen?}

\author{
Antônio Carlos Pedrosa-Soares ${ }^{1} \&$ Fernando Flecha de Alkmim ${ }^{2}$ \\ 1. CPMTC-IGC-UFMG, Belo Horizonte, MG. pedrosa@pq.cnpq.br \\ 2. DEGEO-Escola de Minas-UFOP, Ouro Preto, MG. ffalkmim@pq.cnpq.br
}

Received 18 October 2011, accepted 21 November 2011

\begin{abstract}
The development of the Araçuaí-West Congo orogen (AWCO) started around $630 \mathrm{Ma}$, as suggested by U-Pb ages from the oldest rocks yet found in its pre-collisional magmatic arc. This orogeny was preceded by at least six events of rifting and/or anorogenic magmatism, which affected the area occupied by the AWCO and the adjacent São Francisco-Congo craton, namely: the Statherian E1 (1.771.7 Ga), Calymmian E2 (1.57-1.5 Ga), Early Stenian E3 (1.18 - ? Ga), Stenian-Tonian E4 (ca. 1 Ga), Tonian E5 (930-850 Ma) and Cryogenian E6 (750-670 Ga) events. The E1 event, currently referred to as the Statherian taphrogenesis, took place between ca. $1.77 \mathrm{Ga}$ and $1.7 \mathrm{Ga}$. It is recorded by the rift-related sedimentary and volcanic rocks of the basal section of the Espinhaço Supergroup, as well as the anorogenic plutons of the Borrachudos and Lagoa Real suites. The E1 event was followed by a Calymmian episode, the E2 (ca. 1.57 Ga), recorded in the northern Espinhaço range and Chapada Diamantina by sediments and volcanics of the middle portion of the Espinhaço Supergroup. The manifestations of the Stenian E3 event started around $1.18 \mathrm{Ga}$ with the syn-rift deposition of the Sopa-Brumadinho Formation (Espinhaço Supergroup), exposed in the Araçuaí belt. The first three events (E1, E2 and E3) are so far not found in the West Congo belt. In this belt, a magmatism took place at the Stenian-Tonian time boundary, the anorogenic Noqui granites (ca. $999 \pm 7 \mathrm{Ma}$ ) and related volcanic rocks, recording a probably local extensional event, E4, which can be correlated to mafic dykes of similar age found in southern Bahia (eastern tip of the São Francisco craton). The thick bimodal volcanic pile of the Zadinian and Mayumbian groups and related intrusions are the main records of the Tonian E5 event in the West Congo belt. The A-type Salto da Divisa Suite and Tonian mafic dykes (e.g., Pedro Lessa and Northern Espinhaço range), as well as the deposition of the pre-glacial formations of the Macaúbas basin are manifestations of the E5 event in the Araçuaí orogen and São Francisco craton. Records of the Cryogenian E6 event include the Southern Bahia alkaline province (ca. 735-675 Ma) and, probably, the La Louila felsic volcanism in SW Gabon ( $\leq 713 \mathrm{Ma}$ ), as well as the deposition of the diamictitic formations of the Macaúbas Group and correlatives. The E6 event evolved to oceanic spreading in the central-southern Macaúbas basin, but this process died out toward north keeping unbroken the continental link between the São Francisco peninsula and Congo continent (the Bahia-Gabon bridge). In fact, all those extensional events were unsuccessful in splitting the São Francisco-Congo plate, which amalgamated in the Rhyacian-Orosirian time boundary (ca. $2.05 \mathrm{Ma}$ ) and remained as such until the Lower Cretaceous, as the Atlantic rifting then successfully broke through the old continental mass.
\end{abstract}

Keywords: rift, anorogenic magmatism, Araçuaí-West Congo orogen, São Francisco-Congo craton

RESUMO: QUANTOS EVENTOS DE RIFTEAMENTO PRECEDERAM O DESENVOLVIMENTO DO ORÓGENO ARAÇUAÍ-CONGO OCIDENTAL? A edificação do Orógeno Araçuaí-Congo Ocidental teve início por volta de $630 \mathrm{Ma}$, como indicam as idades U-Pb mais antigas até agora obtidas de rochas do seu arco magmático. Esta orogenia foi precedida de, pelo menos, seis eventos de rifteamento e/ou magmatismo anorogênico que afetaram a região ocupada pelo Orógeno Araçuaí-Congo Ocidental, bem como o domínio cratônico São Francisco-Congo a ele adjacente. São eles os eventos E1 (Estateriano, 1,77-1,7 Ga), E2 (Calimiano, 1,57-1,5 Ga), E3 (Esteniano, 1,18 - ? Ga), E4 (no limite Esteaniano-Toniano, ca. $1 \mathrm{Ga}$ ), E5 (Toniano, 930-850 Ma) e E6 (Criogeniano, 750-670 Ma). O evento E1, chamado de Tafrogênese Estateriana, teve lugar entre 1,77 e 1,70 Ga e tem como registros mais importantes a deposição rifte das unidades sedimentares e vulcânicas da base do Supergrupo Espinhaço, bem como o alojamento dos plutons anorogênicos das suítes Borrachudos e Lagoa Real. O evento E1 é sucedido por uma nova fase de distensão durante o período Calimiano, em torno de 1,57 Ga, que é representada no Espinhaço Setentrional e Chapada Diamantina por rochas sedimentares e vulcânicas da porção média do Supergrupo Espinhaço. Manifestações do evento E3 (Esteniano) tiveram início em torno de 1,18 Ga com a deposição da Formação Sopa-Brumadinho (Supergrupo Espinhaço), exposta na Faixa Araçuaí. Os três primeiros eventos (E1, E2 e E3) parecem não ter ocorrido na Faixa Congo Ocidental. Nesta faixa, os granitos Noqui (999 $\pm 7 \mathrm{Ma}$ ) e rochas vulcânicas associadas representam um magmatismo anorogênico do limite Esteniano-Toniano, registrando um evento provavelmente local (E4), mas que pode ser correlacionável aos diques máficos de idade similar que ocorrem no sul da Bahia, no extremo oriental do Cráton São Francisco. As espessas sucessões de rochas vulcânicas bimodais dos grupos Zadiniano e Mayumbiano (930-910 Ma) constituem os principais registros do evento E5 na Faixa Congo-Ocidental. O magmatismo anorogênico representado pela Suíte Salto da Divisa e enxames de diques máficos tonianos (e.g., Pedro Lessa e Espinhaço Setentrional), assim como, muito provavelmente, os depósitos pré-glaciais da bacia Macaúbas são manifestações de E5, em terrenos do Orógeno Araçuaí e Cráton do São Francisco. O evento criogeniano, E6, é evidenciado pela Província Alcalina do Sul da Bahia entre 735 e 675 Ma, e, muito provavelmente, pelas formações diamictíticas do Grupo Macaúbas e unidades correlativas na Faixa Congo Ocidental, e pelo vulcanismo félsico La Louila ( $\leq 713 \mathrm{Ma}$ ) do sudoeste do Gabão. O evento E6 evoluiu para espalhamento oceânico no setor centro-sul da Bacia Macaúbas, mas este processo não afetou a parte norte desta bacia e, por isto, deixou íntegra a ligação continental (a ponte Bahia-Gabão) entre a Península São Francisco e o Continente Congo. De fato, nenhum dos eventos distensionais mencionados logrou levar à ruptura a placa São Francisco-Congo que, aglutinada na transição Riaciano-Orosiriano (ca. 2,05 Ga), permaneceu íntegra até o Cretáceo Inferior quando, então, o rifte Atlântico finalmente conseguiu desmembrá-la.

Palavras-chave: rifte, magmatismo anorogênico, Orógeno Araçuaí-Congo Ocidental, Cráton São Francisco-Congo

\section{INTRODUCTION}

The history of the continents is punctuated by relatively short intervals of convergence and agglutination, which alternate with long periods of fragmentation and drift (Nance et al. 1988, Murphy
\& Nance 1992). The process of continental convergence and collision that lead to assembly of new and larger continental masses is associated with consumption of oceanic lithosphere, deformation of the plate margins involved, accretion of juvenile material, magmatism and metamorphism. In other 
words, the formation of a new continent, regardless of its size, gives rise to orogenic systems of variable configuration and architecture. Once formed, new continents become a refractory cap hindering hot release from Earth's interior and, thus, providing traps for accumulation of variable amounts of ascending mantle material beneath them. Uprising of hot mantle generally result in continental extension, which is accommodated along rift systems of variable size and styles, accompanied or not by magmatic activity. The larger the continental area, the greater its susceptibility to the action of mantle derived processes.

The piece of Paleoproterozoic continental lithosphere that included the São Francisco and Congo cratons amalgamated by the beginning of the Orosirian period, around $2.05 \mathrm{Ga}$, and remained as such until the generation of the South Atlantic in the Lower Cretaceous (e.g., Ledru et al. 1994, Silva et al. 1997, Alkmim \& Marshak 1998, Barbosa \& Sabaté 2004, Lerouge et al. 2006, Noce et al. 2007, Heilbron et al. 2010). At the time of its assembly, the São Francisco-Congo lithosphere was probably part of a large continent, the so-called Atlantica (Rogers 1996, Rogers \& Santosh 2004).

The Araçuaí-West Congo orogen (AWCO), which encompasses the Araçuaí orogen of southeastern Brazil and the West Congolian belt of southwestern Africa (Fig. 1), developed during the amalgamation of the Gondwana supercontinent by the end of the Neoproterozoic Era (Pedrosa-Soares et al. 2001, 2007; Alkmim et al. 2006, 2007). The AWCO is, thus, just a small portion of a giant orogenic network generated along the margins of the various plates that concurred to form West Gondwana (BritoNeves et al. 1999, Cordani et al. 2003). In this scenario, the AWCO formed as the margins of a terminal branch of the Adamastor ocean surrounded by the São Francisco peninsula and Congo continent, the Macaúbas gulf-like basin, converged and collided (Fig. 1).

This paper discusses a series of extensional and magmatic events that affected the São FranciscoCongo plate in the time interval between its assembly in the Paleoproterozoic and the development of the AWCO during the Gondwana amalgamation by the end of the Neoproterozoic. Results of studies we conducted in the AWCO and adjacent cratonic domains together with literature data indicate that during this $1.5 \mathrm{Ga}$-long period the São Francisco-Congo plate was not affected by contractional events. Rather, it underwent at least six major rifting/magmatic events that led to the development of the Macaúbas basin, precursor of the Araçuaí-West Congo orogen.

\section{GEOTECTONIC SETTING}

The Araçuaí-West Congo orogen evolved from the Macaúbas basin inside an embayment bounded on three sides by the Neoproterozoic continental domain represented by the São Francisco and Congo cratons (Fig. 1). This Neoproterozoic gulf, an inlandsea basin partially floored by oceanic crust, was opened to the Adamastor ocean and connected to aulacogens located in the adjacent continental areas. The aulacogenic branches accommodated the enlargement of the Macaúbas basin and left intact the so-called Bahia-Gabon cratonic bridge, the crustal segment that linked the São Francisco and Congo blocks. The Bahia-Gabon cratonic bridge stood firm until the opening of the South Atlantic in the Lower Cretaceous (e.g., Porada 1989; PedrosaSoares et al. 2001, 2007, 2008; Cordani et al. 2003; Alkmim et al. 2006, 2007).

In southeastern Brazil, the AWCO comprises the external Araçuaí belt and the orogenic core (Fig. 1). The type unit of the Araçuaí belt is the Neoproterozoic Macaúbas Group, which includes rift and passive margin successions (Pedrosa-Soares et al. 1992, 2008, 2011a; Uhlein et al. 1998). Besides the Macaúbas Group, the Araçuaí belt also involves the Archean-Paloeproerozoic basement, Statherian anorogenic granites, Statherian-Mesoproterozoic metasedimentary and metavolcanic rocks of the Espinhaço Supergroup, and anorogenic magmatic rocks of Tonian age, like the A-type granites of Salto da Divisa and mafic dykes (e.g., Dussin \& Dussin 1995, Uhlein et al. 1998, Knauer 2007, Noce et al. 2007, Pedrosa-Soares et al. 2008, Silva et al. 2008, Chemale-Júnior et al. 2011). The orogenic core is made up of granitic and metamorphic high grade rocks, including an Ediacaran magmatic arc (e.g., Pedrosa-Soares et al. 2008, 2011b; Silva et al. 2011).

The African portion of the AWCO is represented by the West Congo belt which involves ArcheanPaleoproterozoic basement and the Neoproterozoic metassedimentary and metavolvanic units of the Zadinian, Mayumbian and West Congolian groups (Tack et al. 2001).

In the areas adjacent to the AWCO, the cratonic domain consists of an Archean-Paleoproterozoic basement partially covered by Statherian, Mesoproterozoic and Neoprotezoic strata. Within the São Francisco craton, the Proterozoic strata occur in three distinct domains, namely, the Paramirim aulacogen (Northern Espinhaço range and Chapada Diamantina), and the São Francisco and Rio Pardo basins. Anorogenic intrusions and mafic dykes, whose ages fall in the interval between $c a$. $1750 \mathrm{Ma}$ and ca. $670 \mathrm{Ma}$, also occur in areas of the São Francisco-Congo craton adjacent to the AWCO (e.g., Teixeira et al. 2000, Rosa et al. 2007, Alkmim \& Martins-Neto 2011). 


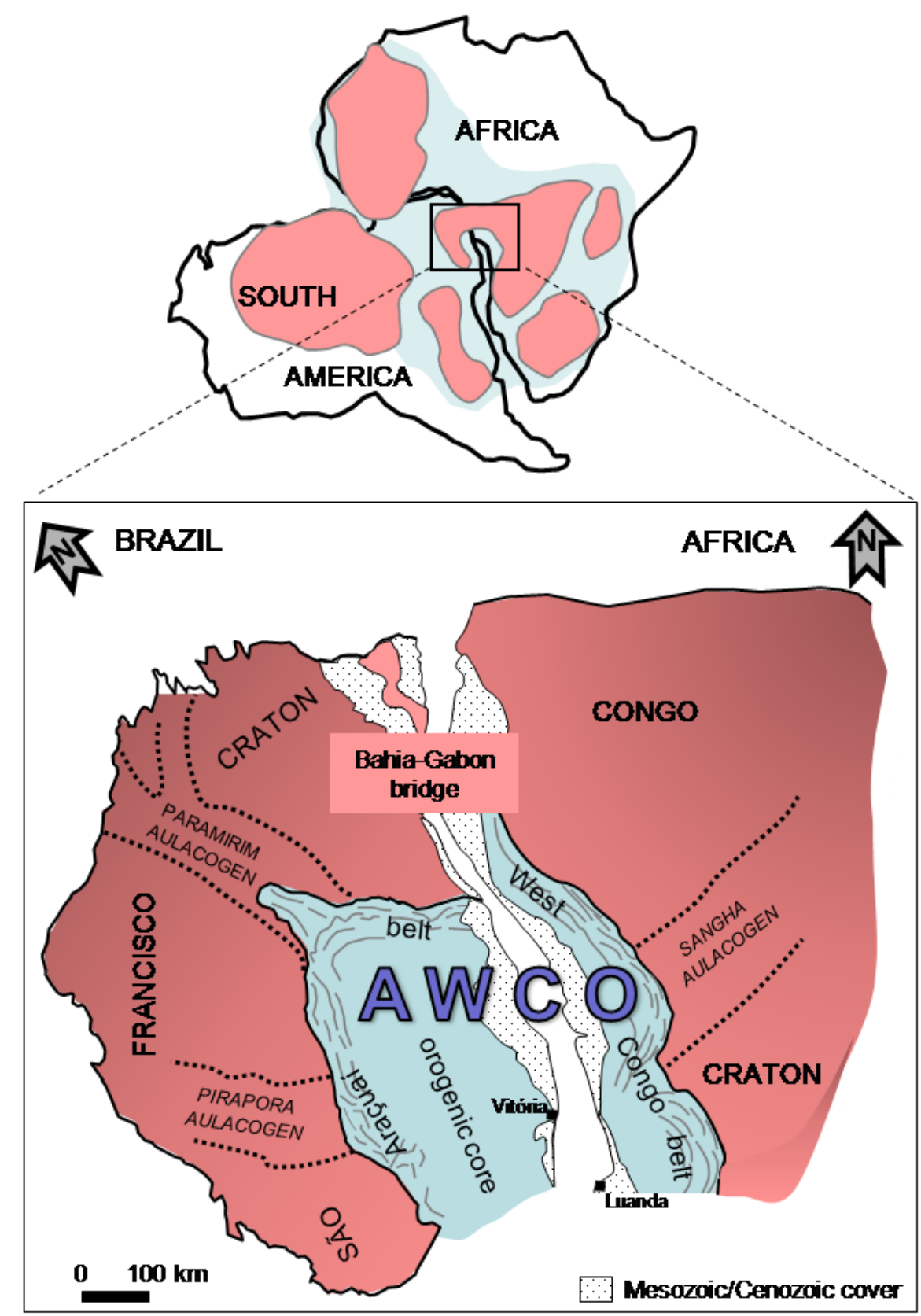

Figure 1. Geotectonic setting of the Araçuaí-West Congo orogen and related aulacogens and cratons (modified from Alkmim et al. 2006).

Figura 1. Situação geotectônica do Orógeno Araçuaí-Congo Ocidental, e aulacógenos e crátons relacionados (modificado de Alkmim et al. 2006).

The onset of the orogenic stage in the AWCO can be traced by the crystallization ages of the oldest igneous bodies formed in the pre-collisional magmatic arc, which have been dated at around 630 $\mathrm{Ma}$. This age constrains the starting time of the convergence of the margins of the precursor basin and consumption of its oceanic lithosphere. The collisional stage reaches its climax around 580-570 $\mathrm{Ma}$, as indicated by the ages of syn-collisional granites and metamorphism (Pedrosa-Soares et al. 2011b, Silva et al. 2011).

\section{THE EVENTS PRECEDING THE DEVELOPMENT OF ARAÇUAÍ-WEST CONGO OROGEN}

A compilation of geochronological data available in the literature, together with results we have obtained in a long term study of the AWCO, led to the conclusion that at least six extensional tectonic and/or anorogenic igneous events preceded the uplift of the orogen, namely: the Statherian E1 (1.77$1.7 \mathrm{Ga})$, Calymmian E2 (1.57-1.5 Ga), Early Stenian E3 (1.18 - ? Ga), Stenian-Tonian E4 (ca. $1 \mathrm{Ga}$ ), Tonian E5 (930-850 Ma) and Cryogenian E6 (750-670 Ga) events (Fig. 2). 


\section{1 - The Statherian E1 event}

The oldest rifting event affecting the São Francisco-Congo plate after its assembly in the Rhyacian/Orosirian transition ( $c a .2 .05 \mathrm{Ga}$ ) is the socalled Statherian taphrogenesis that took place in the time between ca. $1.75 \mathrm{Ga}$ and $1.70 \mathrm{Ga}$ (BritoNeves et al. 1995). Well documented in the Araçuaí orogen and São Francisco craton, the E1 event was so far not found in the West Congo belt and adjacent region of the Congo craton (Tack et al. 2001). The main manifestation of the E1 event is the nucleation of the Espinhaço rift system, which was associated with:

deposition of the basal units of the Espinhaço Supergroup, specifically, the Bandeirinha and São João da Chapada formations of the southern Espinhaço range, the São Simão Formation of the northern Espinhaço range, and the Rio dos Remédios Group (Novo Horizonte Formation) in the Chapada Diamantina (Brito-Neves et al. 1995, Dussin \& Dussin 1995, Schobbenhaus et al. 1996, Uhlein et al. 1998, Guimarães et al. 2008, Loureiro et al. 2008, Danderfer et al. 2009, MartinsNeto 2000, Chemale-Júnior et al. 2010, 2011);

deposition of the base of the Araí Group exposed in the northern Brasília belt (Brito Neves et al. 1995);

- extrusion of a considerable volume of bimodal volcanics, also represented by the basal portion of the Espinhaço Supergroup (Brito Neves et al. 1979, 1995; Schobbenhaus et al. 1994, Babinski et al. 1994, Dusssin \& Dussin 1995, Danderfer et al. 2009, Chemale-Júnior et al. 2011);

- emplacement of the Borrachudos Suite exposed in the southern segment of the Araçuaí belt, which consists of anorogenic granites dated around 1.75 Ga (Grossi Sad et al. 1990, Dussin et al. 1994, ChemaleJúnior et al. 1998, Fernandes 2001, Silva et al. 2002)

emplacement of the protoliths of the Lagoa Real Complex and coeval plutons (São Timóteo Granite) that intrude the basement along the axis of the Paramirim aulacogen (Fernandes et al. 1982, Turpin et al. 1988, Cordani et al. 1992, Pimentel et al. 1994, Arcanjo et al. 2000, Cruz 2004, Cruz et al. 2007).

\section{2 - The Calyminan E2 event}

The second oldest episode of extensional tectonism and magmatism is recorded by the middle portion of the Espinhaço Supergroup in the Paramirim Aulacogen. In the northern Espinhaço range, this episode is represented by alluvial and aeolian sandstones, and acid to intermediate volcanics of the Bomba Formation, which have yielded $\mathrm{U}-\mathrm{Pb}$ ages of $1582 \pm 8 \mathrm{Ma}$ and $1569 \pm 14 \mathrm{Ma}$ (Danderfer et al. 2009). The deposition of alluvial and aeolian sediments of the Tombador Formation (Chapada Diamantina Group), and intrusion of dykes and sills dated around $1.51 \mathrm{Ga}$ are the manifestations of the E2 event in the Chapada Diamantina domain (Babinski et al. 1994, Battilani et al. 2007; Guimarães et al. 2008, Loureiro et al. 2008, Danderfer et al. 2009). Rare 1.51-1.57 Ga detrital zircons occur in the upper Espinhaço Supergroup and younger units involved in the Araçuaí orogen (Babinski et al. 2011, Chemale-Júnior et al. 2011, Gonçalves-Dias et al. 2011). They are the only record of the E2 event yet found in the orogen. The E2 event has not been documented in the West Congo belt and adjacent region of the Congo craton (Tack et al. 2001).

\section{3 - The Early Stenian E3 event}

As recently demonstrated by Chemale-Júnior et al. (2010, 2011), the thick package of alluvial, aeolian and marine sediments of the middle and upper Espinhaço Supergroup exposed in the Araçuaí belt, i.e., the Sopa-Brumadinho and overlaying units, represent a rift-sag sequence (Dussin \& Dussin 1995, Uhlein et al. 1998, Martins-Neto 2000), whose deposition started around $1.18 \mathrm{Ga}$. During the Early Stenian E3 event, the Statherian Espinhaço basin was reactivated and expanded, to host the above mentioned units. However, the upper time limit of the E3 event is not constrained (Fig. 2). Evidence of the $\mathrm{E} 3$ event seems to be absent in the West Congo belt and adjacent region of the Congo craton.

\section{4 - The Stenian-Tonian E4 event}

In the West Congo belt, the anorogenic magmatism represented by the A-type Noqui granites was dated at $999 \pm 7 \mathrm{Ma}$ (Tack et al. 2001). This anorogenic suite records the E4 event, a probable local extensional episode related to opening of the Sangha aulacogen in the StenianTonian time boundary (ca. $1 \mathrm{Ga}$ ). Mafic dykes of similar age found in southern Bahia region (Renne et al. 1990), in the eastern tip of the São Francisco craton, are other potential correlatives of the E4 event (Fig. 2). 
PARAMIRIM AULACOGEN

\section{ESPINHAÇO RANGE}
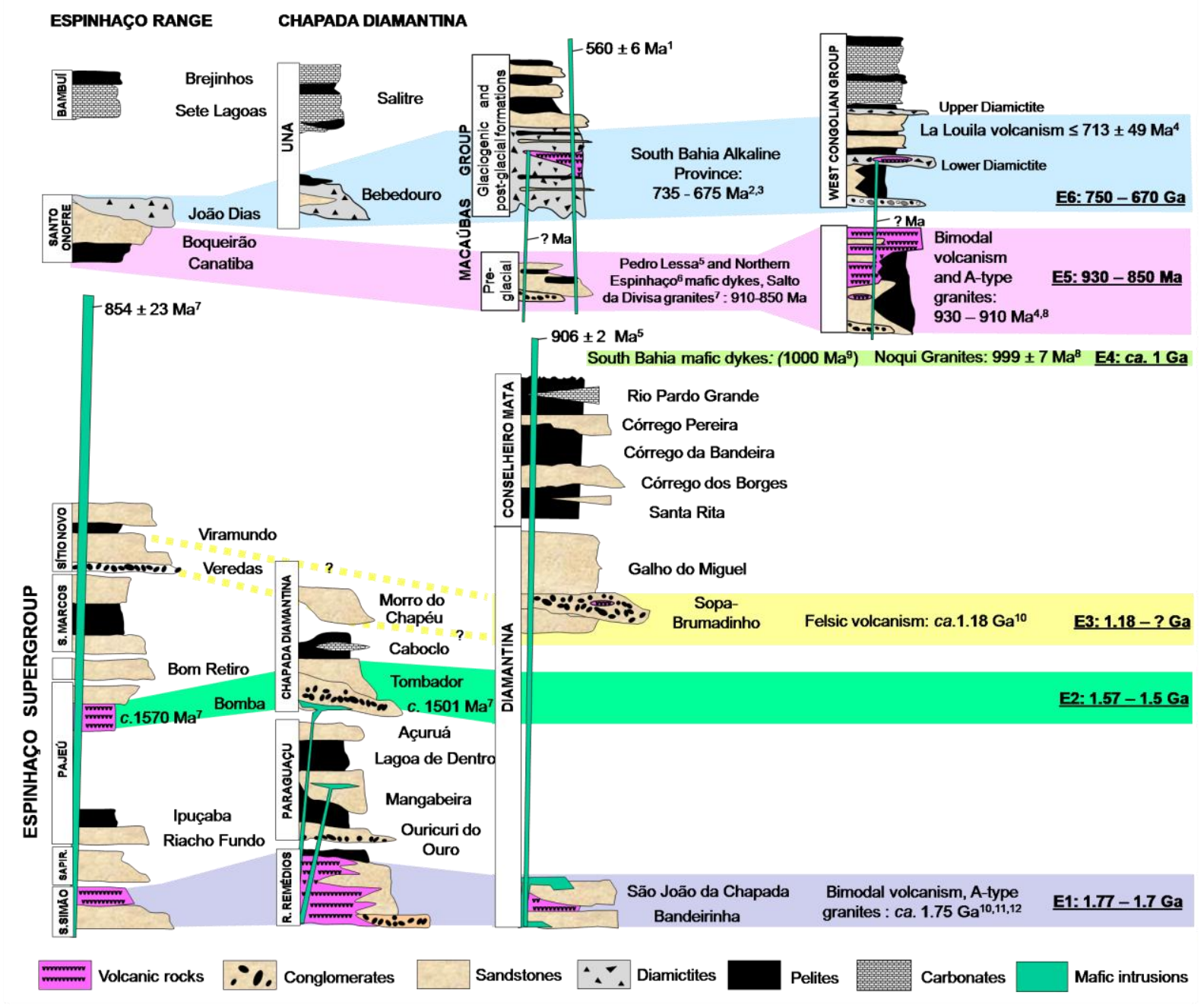

ARAÇUAí BELT

\section{WEST CONGO BELT}

Figure 2. Stratigraphic correlation chart highlighting the rifting and anorogenic magmatic events that preceded the uplift of the Araçuai-West Congo orogen. Ages: 1, Martins et al. (2011); 2, Teixeira et al. (1969); 3, Rosa et al. (2007); 4, Thieblemont et al. (2011); 5, Machado et al. (1989); 6, Danderfer et al. (2009); 7, Silva et al. (2008); 8, Tack et al. (2001); 9, Renne et al.

(1990); 10, Chemale-Júnior et al. (2011); 11, Dussin et al. (1994); 12, Chemale-Júnior et al. (1998).

Figura 2. Carta de correlação estratigráfica, destacando os eventos de rifteamento e magmatismo anorogênico que precederam o soerguimento do Orógeno Araçuaí-Congo Ocidental. Idades: 1, Martins et al. (2011); 2, Teixeira et al. (1969); 3, Rosa et al. (2007); 4, Thieblemont et al. (2011); 5, Machado et al. (1989); 6, Danderfer et al. (2009); 7, Silva et al. (2008); 8, Tack et al. (2001); 9, Renne et al. (1990); 10, Chemale-Júnior et al. (2011); 11, Dussin et al. (1994); 12, Chemale-Júnior et al. (1998).

\section{5 - The Tonian E5 event}

The main record of the E5 Tonian event is the thick bimodal volcanic pile of the Zadinian and Mayumbian groups and related intrusions of the West Congo belt. The Zadinian Group consists of riftrelated siliciclastic sediments and peralkaline rhyolites, covered by a thick succession of mafic volcanic rocks. The Mayumbian Group, which is up to $4 \mathrm{~km}$ thick, consists mostly of felsic volcanic rocks intruded by abundant cogenetic bodies of monzosyenogranite to minor alkali-feldspar granite, and subordinate sedimentary intercalations. Mayumbian volcanic rocks have yielded U-Pb SHRIMP zircon ages of $920 \pm 8 \mathrm{Ma}$ for the lower part of the pile and
$912 \pm 7$ Ma for the upper section of the group (Tack et al. 2001). Together, the Zadinian mafic magmatism and overlying felsic Mayumbian magmatism are a typical example of a bimodal magmatic suite formed during continental rifting (Cahen et al. 1984, Tack et al. 2001). Also, the anorogenic granites and gabbros dated from ca. 904 Ma to ca. 867 Ma by Thieblemont et al. (2011) represent the E4 event in the Gabon sector of the West Congo belt.

Mafic dykes and anorogenic granites are the main records of the E5 event in the Araçuaí belt and São Francisco craton. The Pedro Lessa mafic dyke swarm dated at $906 \pm 7 \mathrm{Ma}$ (Machado et al. 1989) 
represents the E5 event in the Southern Espinhaço range, and basic dykes of ca. $850 \mathrm{Ma}$ record this event in the Northern Espinhaço range (Danderfer et al. 2009). The A-type granites of the Salto da Divisa Suite dated at $875 \pm 9 \mathrm{Ma}$ (Silva et al. 2008) represent the $\mathrm{E} 5$ event along the boundary between the northeastern Araçuaí belt and the São Francisco craton.

Although the subsidence mechanisms of the Macaúbas basin are not well characterized, we consider that the deposition of the diamictite-free (pre-glacial) basal succession of the Macaúbas Group, made up of breccias, conglomerates and sandstones, took place in a rift stage during the $\mathrm{E5}$ event (Pedrosa-Soares et al. 2008, 2011a; Martins et al. 2008; Babinski et al. 2011).

\subsection{The Cryogenian E6 event}

The main record of the E6 event is the emplacement of the voluminous alkaline intrusions that comprise the Southern Bahia alkaline province. These anorogenic intrusions, dated between $c a .735$ $\mathrm{Ma}$ and $c a$. $675 \mathrm{Ma}$, include peralkaline to subalkaline rocks that occur in the eastern sector of the São Francisco craton, close to the boundary to the Araçuaí belt (Teixeira et al. 1969, Rosa et al. 2007).

In the northern portion of the West Congo belt, in Gabon, the La Louila Formation includes rhyolites and rhyolitic tuffs with a maximum age of $713 \pm 49$ Ma (Thieblemont et al. 2011), representing another manifestation of the Cryogenian E6 magmatism.

The glaciogenic diamictitic formations of the Macaúbas Group together with their correlatives in the West Congo belt and cratonic domains (e.g., Jequitaí and Bebedouro formations) might constitute the sedimentary record of the E6 event. Despite of the presence of mafic volcanic rocks intercalated in diamictites of the Macaúbas Group, the attempts to better constrain the age of this riftrelated glacial deposits were so far unsuccessful (Babinski et al. 2005, 2011). The available data indicates that these units accumulated sometime between $900 \mathrm{Ma}$ and $740 \mathrm{Ma}$ (Babinski et al. 2011, Pedrosa-Soares et al. 2011a). The minimum age of $740 \mathrm{Ma}$ is given by the basal portion of the Sete Lagoas Formation, a cap-carbonate dated at $740 \pm$ $22 \mathrm{Ma}$ (Babinski et al. 2007), that overlies the glaciogenic Jequitaí Formation in the interior of the São Francisco craton.

\section{CONCLUSION}

In the region occupied by the Ediacaran AraçuaíWest Congo orogen and adjacent cratonic domains, at least six events of rifting and anorogenic magmatism can be identified, namely: the Statherian E1 (1.77-1.7 Ga), Calymmian E2 (1.57-1.5
Ga), Early Stenian E3 (1.18 - ? Ga), Stenian-Tonian E4 (ca. $1 \mathrm{Ga})$, Tonian E5 (930-850 Ma) and Cryogenian E6 (750-670 Ga) events (Fig. 2). The E6 event evolved to oceanic spreading in the central-southern Macaúbas basin, but this process died out toward north keeping unbroken the continental link (the Bahia-Gabon bridge) between the São Francisco peninsula and Congo continent. In fact, all those extensional events were unsuccessful in splitting the São Francisco-Congo plate, which amalgamated in the Rhyacian-Orosirian time boundary (ca. $2.05 \mathrm{Ma}$ ) and remained as such until the Lower Cretaceous, as the Atlantic rifting then successfully broke through the old continental mass.

The time periods of some of these events seem to be rather long and suggest more than only one single extensional and/or magmatic episode, requiring more detailed sedimentologicalstratigraphic studies accompanied by $\mathrm{U}-\mathrm{Pb}$ geochronological analysis.

\section{ACKNOWLEDGEMENTS}

This paper is a tribute to Carlos Maurício Noce, our unforgettable friend and colleague. We acknowledge the CNPq (Scientific and Technological Research Council of Brazil) for the research grants.

\section{REFERENCES}

Alkmim F.F., Marshak S. 1998. Transamazonian orogeny in the southern São Francisco craton region, Minas Gerais Brazil: evidence for Paleoproterozoic collision and collapse in the Quadrilátero Ferrífero. Precambrian Research, 90: 29-58.

Alkmim F.F., Marshak S., Pedrosa-Soares A.C., Peres G.G., Cruz S., Whittington A. 2006. Kinematic evolution of the AraçuaíWest Congo orogen in Brazil and Africa: Nutcracker tectonics during the Neoproterozoic assembly of Gondwana. Precambrian Research, 149: 43-64.

Alkmim F.F., Pedrosa-Soares A.C., Noce C.M. \& Cruz S.C.P. 2007. Sobre a evolução tectônica do Orógeno Araçuaí-Congo Ocidental. Geonomos, 15: 25-43.

Alkmim F.F., Martins-Neto 2011.Proterozoic first-order sedimentary sequences of the São Francisco craton, eastern Brazil. Marine and Petroleum Geology, doi:10.1016/j.marpetgeo.2011.08.011 (in press).

Arcanjo J.B., Marques-Martins A.A., Loureiro H.S.C., Varela P.H.L. 2000. Projeto Vale do Paramirim, escala 1:100.000. PGBL, CPRM-DNPM.

Babinski M., Brito-Neves B.B., Machado N., Noce C.M., Uhlein A., Van Schmus W.R. 1994. Problemas da Metodologia U-Pb com Zircões de Vulcânicas Continentais: Caso do Grupo Rio dos Remédios, Supergrupo Espinhaço, no Estado da Bahia. In: SBG, Congresso Brasileiro de Geologia, 38, Anais, 2: 409-410.

Babinski M., Gradim R.J., Pedrosa-Soares A.C., Alkmim F.F., Noce C.M. \& Liu D. 2005. Geocronologia U-Pb (SHRIMP) e Sm-Nd de xistos verdes basálticos do Orógeno Araçuaí: Implicações para a idade do Grupo Macaúbas. Revista Brasileira de Geociências, 35 (4-supplement): 77-81.

Babinski M., Vieira L. C. \& Trindade R. I. F. 2007a. Direct dating of the Sete Lagoas cap carbonate (Bambuí Group, Brazil) and implications for the Neoproterozoic glacial events. Terra Nova, 19: 401-406. 
Babinski M., Pedrosa-Soares A.C., Trindade R.I.F., Martins M., Noce C.M., Liu D. 2011. Neoproterozoic glacial deposits from the Araçuaí orogen, Brazil: Age, provenance and correlations with the São Francisco craton and West Congo belt, Gondwana Research, doi:10.1016/j.gr.2011.04.008 (in press).

Barbosa J.S.F., Sabaté P. 2004. Archean and Paleoproterozoic crust of the São Francisco craton, Bahia, Brazil: geodynamic features. Precambrian Research, 133: 1-27.

Battilani G.A., Gomes N., Guerra W.J. 2007. The occurrence of microdiamonds in Mesoproterozoic Chapada Diamantina intrusive rocks, Bahia, Brazil. Anais da Academia Brasileira de Ciências, 79: 321-332.

Brito-Neves B.B., Kawashita K., Cordani U.G., Delhal J. 1979. A evolução gecronológica da Cordilheira do Espinhaço: dados novos e integração. Revista Brasileira de Geociências, 9(1): 71-85.

Brito-Neves B.B., Sá J.M., Nilson A.A, Botelho N.F. 1995. A Tafrogênese Estateriana nos blocos Proterozóicos da América do Sul e processos subsequentes. Geonomos, 3(2):1-21.

Brito-Neves B.B., Campos-Neto M.C., Fuck R.A. 1999. From Rodinia to Western Gondwana: An approach to the Brasiliano-Pan African cycle and orogenic collage. Episodes, 22: 155-199.

Cordani U.G., Brito-Neves B.B., D'Agrella M.S., Trindade R.I.F. 2003. Tearing-up Rodinia: the Neoproterozoic paleogeography of South American cratonic fragments. Terra Nova, 15: 343-349.

Cahen L., Snelling N.J., Delhal J., Vail. J.R. 1984. The Geochronology of Africa. Clarendon Press, Oxford, $512 \mathrm{pp}$.

Chemale-Júnior F., Quade H., Van Schmus W.R. 1998. Petrography, geochemistry and geochronology of the Borrachudos and Santa Bárbara metagranites, Quadrilátero Ferrífero, Brazil. Zbl. Geol. Paläont., 1997. p. 739-750.

Chemale-Júnior. F., Dussin I.A., Martins M.S., Alkmim F.F., Queiroga G. 2010 The Espinhaço Supergroup in Minas Gerais: A Stenian Basin? In: 7th South American Symposium on Isotope Geology, Brasília, p. 552-555.

Chemale-Júnior F., Dussin I., Alkmim F., Martins M.S., Queiroga G., Armstrong R., Santos M. 2011. Unravelling a Proterozoic basin history through detrital zircon geochronology: The case of the Espinhaço Supergroup, Minas Gerais, Brazil, Gondwana Research, doi: 10.1016/j.gr.2011.08.016 (in press).

Cordani U.G., Iyer S.S., Taylor P.N., Kawashita K., Sato K., McReath I. 1992. Pb-Pb, Rb-Sr, and K-Ar sistematic of the Lagoa Real uranium province (south-central Bahia, Brazil) and the Espinhaço Cycle (ca. 1.5-1.0 Ga). J. South Am. Earth Sci., 1: 3346.

Cordani, U.G., Brito-Neves, B.B., D'Agrella, M.S. \& Trindade, R.I.F. 2003. Tearing-up Rodinia: the Neoproterozoic paleogeography of South American cratonic fragments. Terra Nova, 15: 343-349.

Cruz S.C.P. 2004. A interação tectônica entre o Aulacógeno do Paramirim e o Orógeno Araçuaí-Oeste Congo. Tese de Doutorado, Departamento de Geologia, UFOP, 505 p.

Cruz S.C.P., Alkmim F. F., Leite C.M.M., Evangelista H.J., Cunha J.C., Matos E C., Noce C.M., Marinho M.M. 2007. Geologia e arcabouço estrutural do Complexo Lagoa Real, Vale do Paramirim, Centro-Oeste da Bahia. Revista Brasileira de Geociências, 4 (suplemento), 28-146.

Danderfer A., Waele B., Pedreira A.J., Nalini H. A. 2009. New geochronological constraints on the geological evolution of Espinhaço basin within the São Francisco Craton Brazil. Precambrian Research, 170: 116-128.

Dussin T.M., Rossi P., Dussin I.A., Charvet J. 1994. The Borrachudos Suite, Mesoproterozoic A-type granitic magmatism in the southeastrn São Francisco craton (SE Brazil). In: Annexe III, Evoluction structurale de la region de
I'Espinhaço Meridional, bordure sud-est du Craton São Francisco, Brésil. Thése Doctorat, Univ. d'Orléans, p. 1-35.

Dussin I.A., Dussin T.M. 1995. Supergrupo Espinhaço: Modelo de evolução geodinâmica. Geonomos, 3: 19-26.

Fernandes P.E.C.A., Montes M.L., Braz E.R.C., Silva L.L., Oliveira F.L.L., Ghignone J.I., Siga Jr. O., Castro H.E.F. 1982. Geologia. In: BRASIL. Ministério das Minas e Energia. Secretaria Geral. Projeto RADAMBRASIL. Folha SD.23 Brasília: geologia, geomorfologia, pedologia, vegetação e uso potencial da terra. Rio de Janeiro, p. 25-204.

Fernandes M.L.S. 2001. O Granito Borrachudos na região entre Guanhães e Dores de Guanhães, MG (Plutonito Morro do Urubu): gênese e evolução. Tese de Doutorado, Universidade Federal do Rio de Janeiro. $110 \mathrm{p}$.

Gonçalves-Dias T., Pedrosa-Soares A.C., Dussin I.A., Alkmim F.F., Caxito F.A., Silva L.C., Noce C.M. 2011. Idade máxima de sedimentação e proveniência do Complexo Jequitinhonha na área-tipo (Orógeno Araçuaí): primeiros dados U-Pb (LA-ICPMS) de grãos detríticos de zircão. Geonomos, 19(2): 121-130.

Grossi-Sad J.H., Chiodi C., Santos J.F., Magalhães J.M.M., Carelos P. 1990. Duas suítes graníticas do bordo sudeste do Cráton Sanfranciscano, em Minas Gerais: petroquímica e potencial metalogenético. In: Cong Bras Geol, 36., Anais, Natal, SBG, 4: 1836-1848.

Guimarães J.T., Santos R.A.S., Melo R.C. 2008. Geologia da Chapada Diamantina Ocidental. In: Guimarães J.T., Santos R.A., Melo R.C. Projeto Ibitiara - Rio de Contas. CBPM / CPRM, Salvador, Arquivos Abertos 31, $64 \mathrm{p}$.

Heilbron M., Duarte B., Valeriano C., Simonetti A., Machado N., Nogueira J. 2010. Evolution of reworked Paleoproterozoic basement rocks within the Ribeira belt (Neoproterozoic), SEBrazil, based on U-Pb geochronology: Implications for paleogeographic reconstructions of the São Francisco-Congo paleocontinent. Precambrian Research, 178: 136-148.

Knauer L.G. 2007. O Supergrupo Espinhaço em Minas Gerais: considerações sobre sua estratigrafia e seu arranjo estrutural. Geonomos, 15(1): 81-90.

Ledru P.J., Johan V., Milési J.P., Teguy M. 1994. Markers of the last stage of the Paleoproterozoic collision: evidence for a $2 \mathrm{Ga}$ continent involving circum-South Atlantic provinces. Precambrian Research, 69: 169-191.

Lerouge C., Cocherie A., Toteu S.F., Penaye J., Milési J.-P., Tchameni R., Nsifa E.N.C., Fanning M., Deloule E. 2006. Shrimp U-Pb zircon age evidence for Paleoproterozoic sedimentation and $2.05 \mathrm{Ga}$ syntectonic plutonism in the Nyong Group, South-Western Cameroon: consequences for the Eburnean-Transamazonian belt of NE Brazil and Central Africa. Journal of African Earth Sciences, 44: 127-413.

Loureiro H.S.C., Bahiense I.C., Neves J.P., Guimarães J.T., Teixeira L.R., Santos R.A., Melo R.C. 2008. Geologia e recursos minerais da parte norte do corredor de deformação do Paramirim: (Projeto Barra - Oliveira dos Brejinhos). CBPM, Salvador, Série Arquivos Abertos 33, $113 \mathrm{p}$.

Machado, N. Schrank A., Abreu F.R., Knauer L.G. \& Almeida-Abreu P.A. 1989. Resultados preliminares da geocronologia U-Pb na Serra do Espinhaço Meridional. Boletim do Núcleo Minas Gerais-Sociedade Brasileira de Geologia, 10: 171-174.

Martins, M. S., Karfunkel, J., Noce, C. M., Babinski, M., PedrosaSoares, A. C., Sial, A. N. \& Lyu, D. 2008. A seqüência préglacial do Grupo Macaúbas na área-tipo e o registro da abertura do rifte Araçuaí. Revista Brasileira de Geociências, 38: 768-779.

Martins M.S., Babinski M., Noce C.M., Queiroga G., PedrosaSoares A.C., Trindade R., Liu D. 2011. A Suíte Córrego Taquari no Anticlinal de Itacambira, Bacia do Rio Macaúbas (MG): magmatismo básico tardi-ediacarano (ca. $560 \mathrm{Ma}$ ) no domínio externo do Orógeno Araçuaí. Geonomos, 19(2): 7889. 
Martins-Neto M.A., 2000. Tectonics and sedimentation in a paleo/mesoproterozoic rift-sag basin (Espinhaço basin, southeastern Brazil). Precambrian Research, 103: 147-173.

Murphy J.B., Nance R.D. 1992. Mountain belts and the supercontinent cycle. Scientific American, April 1992, p. 84-91

Nance R.D., Worsley T., Moody J.B. 1988. The supercontinent cycle. Scientific American, July 1988, p. 44-51

Noce C.M., Pedrosa-Soares A.C., Silva L.C., Armstrong R., Piuzana D. 2007. Evolution of polyciclic basement complexes in the Araçuaí orogen, based on U-Pb SHRIMP data: Implications for Brazil-Africa links in Paleoproterozoic time. Precambrian Research, 159: 60-78.

Pedrosa-Soares A.C., Noce C.M., Vidal P., Monteiro R.L.B.P., Leonardos O.H. 1992. Toward a new tectonic model for the Late Proterzoic Araçuaí (SE Brazil) - West Congolian (SW Africa) Belt. Journal of South American Earth Sciences, 6: 3347.

Pedrosa-Soares A.C., Noce C.M., Wiedemann C.M., Pinto C.P. 2001. The Araçuaí-West Congo orogen in Brazil: An overview of a confined orogen formed during Gondwanland assembly. Precambrian Research, 110: 307-323.

Pedrosa-Soares A.C., Vidal P., Leonardos O.H., Brito-Neves B.B. 1998. Neoproterozoic oceanic remnants in eastern Brazil: Further evidence and refutation of an exclusively ensialic evolution for the Araçuaí-West Congo Orogen. Geology, 26: 519-522.

Pedrosa-Soares, A.C., Noce, C.M., Alkmim, F.F., Silva, L.C., Babinski, M., Cordani, U., Castañeda, C. 2007. Orógeno Araçuaí: síntese do conhecimento 30 anos após Almeida 1977. Geonomos, 15: 1-16.

Pedrosa-Soares A.C., Alkmim F.F., Tack L., Noce C.M., Babinski M., Silva L.C., Martins-Neto M. 2008. Similarities and differences between the Brazilian and African counterparts of the Neoproterozoic Araçuaí-West Congo Orogen. In: Pankhurst, J.R.; Trouw, R.A.J.; Brito Neves, B.B.; De Wit, M.J.(eds) West Gondwana: Pre-Cenozoic Correlations across the South Atlantic Region. Geological Society of London, Spec. Publ., 294: 153-172.

Pedrosa-Soares A.C., Babinski M., Noce C., Martins M., Queiroga G., Vilela F. 2011a. The Neoproterozoic Macaúbas Group (Araçuaí orogen, SE Brazil) with emphasis on the diamictite formations. In: Arnaud, E., Halverson, G. P. \& Shields-Zhou, G. (eds), The Geological Record of Neoproterozoic Glaciations. Geological Society, London, Memoirs, 36: 523-534.

Pedrosa-Soares A.C., De Campos C., Noce C.M., Silva L.C., Novo T., Roncato J., Medeiros S., Castañeda C., Queiroga G., Dantas E., Dussin I., Alkmim F.F. 2011b. Late NeoproterozoicCambrian granitic magmatism in the Araçuaí orogen (Brazil), the Eastern Brazilian Pegmatite Province and related mineral resources. Geological Society, London, Spec. Publ., 350: 2551.

Pimentel M. M., Machado N., Lobato L.M. 1994. Geocronologia U$\mathrm{Pb}$ de rochas graníticas e gnáissicas da região de Lagoa Real, Bahia, e implicações para a idade da mineralização de urânio. In: Congresso Brasileiro de Geologia, 38, SBG, Boletim de Resumos Expandidos, p. 389-390.

Porada H. 1989. Pan-African rifting and orogenesis in southern to equatorial Africa and Eastern Brazil. Precambrian Research, 44: 103-136.

Rosa M.L.S., Conceição H., Macambira M., Galarza M.C., Cunha M., Menezes R., Marinho M.M., Cruz-Filho B.E., Rios D.C. 2007. Neoproterozoic anorogenic magmatism in the Southern Bahia Alkaline Province of NE Brazil: U-Pb and Pb$\mathrm{Pb}$ ages of the blue sodalite syenites. Lithos, 97: 88-97.

Renne P.R., Onstott T.C., D'Agrella-Filho M.S., Pacca I.G., Teixeira W. $1990 .{ }^{40} \mathrm{Ar} /{ }^{39} \mathrm{Ar}$ dating of $1.0-1.1 \mathrm{Ga}$ magnetizations from the São Francisco and Kalahari Cratons: tectonic implications for Pan-African and Brasiliano mobile belts. Earth Planet. Science Letters, 101: 349-366.

Rogers J.J.W. 1996. A history of continents in the past three billion years. Journal of Geology, 104 (1): 91-107.

Rogers J.J.W. \& Santosh M. 2004. Continents and supercontinents. Oxford University Press.

Schobbenhaus C. 1996. As tafrogêneses superpostas Espinhaço e Santo Onofre, Estado da Bahia: revisão e novas propostas. Revista Brasileira de Geociências, 26(4): 265-276.

Schobbenhaus C., Hoppe A., Baumann A., Lork A. 1994. Idade U $\mathrm{Pb}$ do vulcanismo Rio dos Remédios, Chapada Diamanatina, Bahia. In: SBG, Congresso Brasileiro de Geologia, 38, Boletim de Resumos Expandidos, v. 2, p. 397-398.

Silva L.C., McNaughton, N.J., Melo R.C., Fletcher I.R. 1997. U-Pb SHRIMP ages in the Itabuna-Caraíba TTG high-grade complex: the first window beyond the Paleoproterozoic overprinting of the eastern Jequié craton, NE Brazil. In: International Symposium on Granites and Associated Mineralizations, 2, Salvador. Proceedings, Sociedade Brasileira de Geologia, 282283.

Silva L.C., Armstrong R., Noce C.M., Carneiro M.A.,Pimentel M., Pedrosa-Soares A.C., Leite C.A., Vieiro V.S., Silva M.A., Paes V., Cardoso-Filho J.M. 2002. Reavaliação da evolução geológica em terrenos Pré- Cambrianos brasileiros com base em novos dados U-Pb SHRIMP, parte II: Orógeno Araçuaí, Cinturão Mineiro e Cráton São Francisco Meridional. Revista Brasileira Geociências, 32: 161-176

Silva L.C., Pedrosa-Soares A.C., Teixeira L.R., Armstrong R. 2008 Tonian rift-related, A-type continental plutonism in the Araçuaí Orogen, eastern Brazil: New evidence for the breakup stage of the São Francisco-Congo Paleocontinent. Gondwana Research, 13: 527-537.

Silva L.C., Pedrosa-Soares A.C., Armstrong R., Noce C.M. 2011. Determinando a duração do período colisional do Orógeno Araçuaí com base em geocronologia U-Pb de alta resolução em zircão: uma contribuição para a história da amalgamação do Gondwana Ocidental. Geonomos, 19(2): 180-197.

Tack L., Wingate M.T., Liégeois J.-P., Fernandez-Alonso M., Deblond A. 2001. Early Neoproterozoic magmatism (1000$910 \mathrm{Ma}$ ) of the Zadinian and Mayumbian Groups (Bas-Congo): onset of Rodinian rifting at the western edge of the Congo craton. Precambrian Research, 110: 277-306.

Teixeira W., Kamo S.L., Arcanjo J.B.A. 1997. U-Pb zircon and baddeleyte age and tectonic interpretation of the Itabuna alkaline suite, São Francisco Craton, Brazil. Journal of South America Earth Sciences, 10: 91-98.

Teixeira W., Sabaté P., Barbosa J., Noce C.M., Carneiro M.A. 2000 Archean and Paleoproterozoic tectonic evolution of the São Francisco Craton. In: Cordani U.G., Milani E.J., Thomaz-Filho A., Campos D.A. (eds.), Tectonic Evolution of South America, Rio de Janeiro, 31st International Geological Congress, pp. 101-138.

Thiéblemont D., Prian J.P., Goujou J.C., Boulingui B., Ekogha H., Kassadou A.B., Simo-Ndounze S., Walemba A., Préat A. Theunissen K., Cocherie A., Guerrot C. 2011. Timing and characteristics of Neoproterozoic magmatism in SW-Gabon: First geochronogical and geochemical data on the WestCongolian orogen in Gabon (SYSMIN project, Gabon 20052009). In: 23 Colloquium of African Geology, posters and abstracts.

Turpin L., Maruèjol P., Cuney M. 1988. U-Pb, Rb-Sr and Sm-Nd chronology of granitic basement, hydrothermal albitites and uranium mineralization, Lagoa Real, South Bahia, Brazil. Contrib. Mineral. Petrol., 98: 139-147.

Uhlein A., Trompette R., Egydio-Silva M. 1998. Proterozoic rifting and closure, SE border of the São Francisco Craton, Brazil. Journal of South American Earth Sciences, 11: 191-203. 